\title{
Assessing the Technological Pedagogical Content Knowledge of Pre-Service Science Teachers at a South African University
}

\author{
Umesh Ramnarain, University of Johannesburg, South Africa \\ Annesca Pieters, University of Johannesburg, South Africa \\ Hsin-Kai Wu, University of Johannesburg, South Africa \& National Taiwan Normal University, Taiwan \\ (iD) https://orcid.org/0000-0003-0018-9969
}

\begin{abstract}
The purpose of this study was to investigate preservice science teachers' proficiency levels regarding their practical knowledge of technological pedagogical content knowledge (TPACK-P). A sample of 103 third- and fourth-year participants from a South African university were surveyed on their TPACK-P proficiency levels using a 17-item questionnaire developed by Yeh, Lin, Hsu, Wu, and Hwang. Rasch analysis was employed to analyse the data. The findings of the study showed that the great majority of preservice science teachers have a proficiency level of 3 for their knowledge on TPACK-P. A proficiency level of 3 demonstrates the infusive application, where the teacher makes use of ICTs to guide learners to self-explore and independently construct their science knowledge. These baseline findings could inform higher education institutions in reviewing their teacher development programmes for pre-service science teacher preparedness in harnessing the affordances of ICT in their teaching.
\end{abstract}

\section{KEYWORDS}

Preservice Science Teachers, Rasch Analysis, Technology Integration, TPACK-P

\section{INTRODUCTION}

Advances in information and communication technology (ICT) have diversified teacher instruction and it is claimed that "ICTs have the potential to improve the quality of education and training" (Department of Basic Education, 2004, p. 8). This is imperative for the integration of ICT in learning expressed through South Africa's White Paper 7 on e-Education (Department of Basic Education, 2004), where it is stated that "ICTs can advance higher order thinking skills such as comprehension, reasoning, problem-solving, creative thinking and enhance employability" (p. 14). Furthermore, with regards to teaching it is asserted that "e-Education will connect learners and teachers to better information, ideas and to one another via effective combinations of pedagogy and technology in support of educational reform" (p. 14). By having this resource at hand, teachers will have access to the needed information to allow them to explain content in a more comprehensible way but also demonstrate it to learners (Ramnarain \& Moosa, 2017). In South Africa, ICT integration is also seen as having a transformational effect in advancing national educational goals such as equity and quality in an education system that has historically marginally Black students (Ford \& Botha, 2010;

\section{DOI: 10.4018/IJICTE.20210701.oa8}

\footnotetext{
This article, published as an Open Access article on April 23rd, 2021 in the gold Open Access journal, the International Journal of Information and Communication Technology Education (converted to gold Open Access January 1st, 2021), is distributed under the terms of the Creative Commons Attribution License (http://creativecommons.org/licenses/by/4.0/) which permits unrestricted use, distribution, and production in any medium, provided the author of the original work and original publication source are properly credited.
} 
Ramnarain \& Modiba, 2013). Given the potential contribution of ICT to learning, there is a need to study more closely teacher competency in their instructional actions when integrating ICT into their teaching practice.

\section{TPACK and TPACK-P Frameworks}

The appropriateness of pedagogical representation selections and planned learning activity designs involving ICTs are determined by teachers' technological pedagogical content knowledge (TPACK). According to Van Driel, Verloop, and de Vos (1998), TPACK, like Pedagogical Content Knowledge (PCK) that was pioneered by Shulman (1986) is regarded as craft knowledge that teachers use when they support students in constructing understanding of an idea or domain (Hsu, Yeh, \& Wu, 2015). TPACK is defined by Koehler, Mishra and Cain (2013) as "the basis of effective teaching with technology requiring an understanding of the representation of concepts using technology" (p.16). It is important for teachers to have the necessary TPACK to ensure that ICT integration in the classroom will be effective. Further to this, Jen, Yeh, Hsu, Wu, and Chen (2016) explain the TPACK of teachers will allow the teaching of topics to be more understandable to learners.

Mishra and Koehler (2006) conceptualised TPACK using Shulman as a basis, where they added "technology to the two knowledge bases of pedagogy and content, to explain technology-supported teaching and learning" (p. 46). Their framework on TPACK puts more emphasis on the "connections, interactions, affordances, and constraints between and among content, pedagogy and technology" (p. 1025). These knowledge bases of teachers cannot be isolated and will always be intertwined with one another to ensure that effective teaching will take place. As seen in Figure 1, Mishra and Koehler (2006) developed a model that emphasises the "complex interplay of these three bodies of knowledge" (p. 1025).

The above framework demonstrates the working of TPCK when it was originally developed. The framework for technological pedagogical content knowledge is now known as TPACK. As seen in the above framework, teachers must ensure that they have a good knowledge or understanding of how to use technology as a foundation for teaching content in the classroom, The above framework also

Figure 1. Technological pedagogical content knowledge framework (Adapted from Mishra and Koehler 2006)

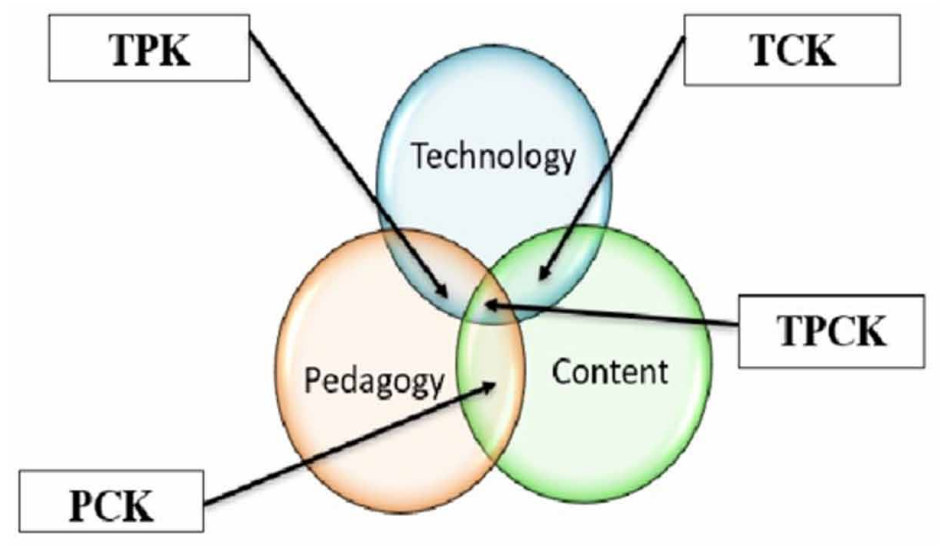

\section{(Adapted from Mishra and Koehler 2006)}


demonstrates the vast amount of knowledge teachers must have to ensure that they will have a welldeveloped TPACK. The TPACK framework allows for the utilisation of better teaching techniques, that allows teachers to implement technology-assisted teaching effectively allowing for a deeper approach to the content. Jen, Yeh, Hsu, Wu and Chen (2016) explained that teachers in our "digital age" should ensure that they know how to use technology properly in their classrooms (p. 46).

Various models of TPACK have evolved from different perspectives on the role of ICT integration (Ay, Karadag \& Acat, 2015). In large part, these models address knowledge and skill dimensions independent of teaching experience. The TPACK-Practical model (TPACK-P) however, focuses on teaching experience and is a knowledge framework for science teachers that "considers the teaching process as the basis upon which application knowledge (teaching experience) and TPACK skills work together" (Ay, Karadag \& Acat, 2015, p.98). Within the model of TPACK-P, there are three knowledge domains that play an important role in a teaching environment: Planning and designing, practical teaching, and assessment.

The planning and designing domain refer to the techniques that teachers use to prepare the curriculum adaptively with the considerations of learners' individuality and features of the target curriculum. Yeh et al., (2015) explained that planning and designing is when "teachers prepare for upcoming teaching practices" (p. 79). When teachers are planning and preparing for their lessons, they must consider the different teaching techniques they are going to use in the lesson but also the learners' knowledge of what the topic demands. When teachers understand what learners understand, but also what they struggle with, the lesson plan can be improved using various teaching techniques, including technology. With technology as a teaching technique, misconceptions that learners might have on a concept can be included in the lesson planning and teachers can retrieve different educational videos to demonstrate the concept.

The practical teaching domain involves teaching practically and employing the various techniques to ensure that ICT-integrated instruction can be carried out smoothly in various learning contexts. In science education, teachers cannot rely on theoretical knowledge alone; practical application of the theoretical knowledge plays an important part in learners' understanding. Yeh et al. (2015) explained: "Science teaching needs to guide and support students as they explore nature and make inquiries, while ICTs offer stimuli, representations and channels" (p. 80). Concepts within science need to be practically implemented in the classroom to ensure that learners grasp the content. Even though chemicals are expensive for some schools, the use of technology can improve the practical teaching of some practical concepts. Teachers do not have to rely on the use of chemicals to demonstrate the effects to learners, technology can be used to virtually demonstrate the theoretical concepts to the learners. Yeh, Lin Hsu, Wu and Hwang (2015) explain that "ICTs offer stimuli, representations, and channels to accommodate preservice science teachers with heterogeneous cognitive development in different inquiry activities" (p. 80).

Lastly, the assessment domain involves assessing how learners are using multiple techniques to construct knowledge (Yeh, Hsu, Wu, Hwang, \& Lin, 2015). The assessment domain also includes the techniques teachers use that inform them about their learners. In science education, learners develop misconceptions on concepts, and this can affect their overall understanding. Technology can be used to continuously assess the learners in a lesson on concepts that poses a problem. TPACK-P suggest that teachers' knowledge in ICT-infused assessment is critical, since it determines how well they assess students' learning with proper ICT tools and strategies (Falk 2012; Fan, Wang \& Wang, 2012).

\section{ICT and Teacher Education}

The roll-out of the technology in our South African classrooms can have a positive impact on the education of our learners but there are also a few barriers to this technology-assisted teaching. Teachers are not all trained in the effective implementation and the use of technology in their classrooms. Jen, Yeh. Hsu, Wu and Chen (2016) explain that the "lack of necessary knowledge and confidence" contributes to the unsuccessful usage of technology (p. 45). Mumtaz (2000) stated a list of inhibitors 
has been found in previous studies. A few of the barriers to the limited use, is the "lack of teaching experience with ICT, lack of on-site support for teachers using technology, lack of supervision of children when using computers, lack of ICT specialist teachers to teach students computer skills, lack of computer availability, and lack of financial support." (p. 320). Mishra and Koehler (2006) further explains that "teachers will have to do more than simply learn to use currently available tools; they will also have to learn new techniques and skills, as current technologies become obsolete" (p.1023). Consequently, as technology becomes outdated every year, teachers should stay updated to ensure they will use technology effectively with different techniques. To ensure that teachers stay updated with all technological developments, "teachers need to be provided with adequate facilities and training to be able to use those facilities, in order to progress in technology-rich context" (Mumtaz, 2000, p.336). The South African White Paper on e-learning emphasizes the role of higher education institutions such as universities in ensuring the preparation of teachers to effectively integrate ICT in their teaching (Department of Education, 2004). This is revealed in the excerpt below from this document:

Accredited pre-service teacher training programmes will provide students with the basic knowledge, skills and attitudes required to integrate ICTs into subjects of specialisation. This will require that each graduating teacher is able to combine knowledge of the learning process and instructional systems theory with various forms of media and learning environments, to create the most effective and efficient learning experiences. (p.27)

With the use of surveys and questionnaires, researchers have tried different approaches in investigating teachers' TPACK. These surveys and questionnaires allow teachers to choose answers on these surveys and questionnaires that is more suitable to their understanding of TPACK. The resulting information has not only revealed how well teachers' knowledge and application is developed on teaching with technology, but constructive directions for future teacher education was also established. There is thus a renewed sense of urgency for teacher education institutions to adequately prepare teachers to fulfil this mandate of technology-assisted teaching.

This research provides information on the competency of student teachers in science education implementing ICT use in their classrooms and identifying specific gaps in teacher TPACK such as ICT-integrated teaching strategies, ICT to assess learners and ICT and instructional management. This baseline information could be useful for higher education institutions in reviewing their teacher development programmes for student science teachers. According to Lux, Bangert and Whittier (2011), is important "for evaluating the quality of instructional technology training that occurs in teacher preparation programs (p. 419). Yeh et al., (2014) elaborated that teacher education programs should not only focus on the integration of technology but also on the experiences of teachers using technology in the classroom. The research was guided by the following question:

What is the TPACK-P proficiency of preservice science teachers?

\section{RESEARCH DESIGN AND METHODOLOGY}

This research adopted quantitative design in collecting data from a sample of 103 Life, Natural and Physical Sciences pre-service science teachers at a South African university. The students were either in their third or fourth year of a four year Bachelor of Education qualification. The decision to focus on this cohort of students was due to them been orientated towards TPACK in their methodology modules in these years of study, and having experience in the integration of ICT during their teaching practicum at schools. The data was collected by means of a questionnaire developed by Yeh et al. (2015). The questionnaire based on the TPACK-P framework comprises 17 items that describe instructional scenarios on science teachers' implementation of ICTs in their instruction. Hence, the items solicit data on teachers' TPACK-P proficiency levels. This instrument had been administered previously to preservice teachers (Jen, Yeh, Hsu, Wu, \& Chen, 2016), and was deemed by researchers at three local universities to be valid in terms of constructs being addressed for the same targeted group of participants in South Africa. The items were also piloted with the same year group of South 
African university students pursuing a Bachelor of Education qualification at another university, and the readability of the items was confirmed. The items in the questionnaire are clustered together according to the three knowledge dimensions mentioned earlier. Questions one to six focus on the assessment dimension of the preservice science teachers. Questions seven to 13 focus on the planning and designing knowledge dimension. Lastly questions 14 to 17 focus on the enactment knowledge dimension. Table 1 shows how the 17 items of the questionnaire were clustered according to the three different knowledge domains of TPACK-P, known as planning and designing, practical teaching and assessment.

Each item has four options that individually represent typical performances that teachers at levels 1 to 4 display. Level 4 (reflective application) is the highest proficiency level that science teachers could achieve, and it indicates that they are adept at using their experience based TPACK to employ ICTs in assisting their learners in learning about science. Teachers at level 3 (infusive application) use ICTs to guide students to self-explore and independently construct their science knowledge, whereas teachers at level 2 (simple adoption) use ICTs to help learners learn about science but via more teacher-centred strategies or with less well-founded rationales. Level 1 represents teachers that only have a basic understanding of technology resulting from their lack of, or limited experience, negative impressions regarding technology in the classroom, or a lack of intention to implement ICTs in their classrooms. For example, item 1 that focused on the assessment domain, was formulated as follows: How do you think your use of videos/animation in the classroom helps you to better understand your students' learning? The following options were offered to students:

A. They help me learn how students feel about the use of videos /animation in instruction.

B. They help me assess students' content comprehension through dynamic presentations.

C. They help me elicit students' prior knowledge and/or misconceptions.

D. I don't believe videos /animation are useful for assessing students' individual differences.

Option C represents a performance at level 4, option B at level 3, option A at level 2 and option $\mathrm{D}$ at level 1.

The data collected was analysed by employing Rasch analysis. The mean score and standard deviation for the frequency with which the preservice science teachers select an option corresponding to a proficiency level was calculated. Reliability (internal consistency) for the instrument was established by calculating Cronbach's alpha. Knowledge differences between the 103 preservice science teachers were explored by applying a unidimensional Partial-Credit Model (PCM) to the response data collected from the TPACK-P questionnaire. All responses on the 17 questions were scored according to the corresponding proficiency level (i.e., 1, 2, 3, 4). A blank response was scored as 0 , referring to proficiency level 0 where "the respondent had no idea how to use technology in a science class" (Jen et al., 2016, p. 51). The data collected were analysed using item response theory (IRT), by employing Rasch modelling. The four options for each item were designed to represent the four proficiency levels. Proficiency level 1 was coded 1, proficiency level 2 as 2, proficiency level 3 as 3 , and proficiency level 4 as 4 .

The Rasch analysis does not require the student to answer all the items in the questionnaire and preservice science teachers can still be compared on a "single equal-interval scale" (Boone, 2014, p. 8). For this study the single equal-interval scale that preservice science teachers were compared with, is that of their proficiency level in their knowledge of TPACK-P. In answering the questionnaire, the students were instructed to select an option that they most agreed with in relation to the instructional scenario's that were provided to them. Their responses were not regarded as right or wrong but coded by proficiency levels (Masters, 1988). Preservice science teacher's TPACK-P were estimated with weighted likelihood ability estimates. Weighted likelihood estimates (WLEs) were proposed by Warm (1989), providing "a bias correction to the maximum likelihood method by solving a weighted loglikelihood equation" (Tao, Shi \& Chang, 2012, p. 298). 
Table 1. Item clusters under the three knowledge domains of TPACK-P

\begin{tabular}{|c|c|c|c|c|c|}
\hline \multicolumn{6}{|c|}{ KNOWLEDGE DOMAINS } \\
\hline \multicolumn{2}{|r|}{ Planning and Designing } & \multicolumn{2}{|r|}{ Practical teaching } & \multicolumn{2}{|r|}{ Assessment } \\
\hline 7. & $\begin{array}{l}\text { Learning about subject content } \\
\text { using technology. }\end{array}$ & 14. & $\begin{array}{l}\text { Why technology-supported } \\
\text { instruction is considered } \\
\text { special. }\end{array}$ & 1. & $\begin{array}{l}\text { Use of video's/ animation in } \\
\text { the classroom helps to better } \\
\text { understand student learning. }\end{array}$ \\
\hline 8. & $\begin{array}{l}\text { Types of subject content suited } \\
\text { to teaching with technology- } \\
\text { supported instruction. }\end{array}$ & 15. & $\begin{array}{l}\text { Opinion regarding } \\
\text { synchronous and } \\
\text { asynchronous } \\
\text { communications. }\end{array}$ & 2. & $\begin{array}{l}\text { Simulations help to identify } \\
\text { learning difficulties. }\end{array}$ \\
\hline 9. & $\begin{array}{l}\text { Factors influencing teachers } \\
\text { planning and designing of } \\
\text { technology-supported instruction. }\end{array}$ & 16. & $\begin{array}{l}\text { Handling of problems } \\
\text { with technology-supported } \\
\text { instruction. }\end{array}$ & 3. & $\begin{array}{l}\text { Usefulness of technology } \\
\text { integration helping preservice } \\
\text { science teachers with different } \\
\text { learning styles and needs. }\end{array}$ \\
\hline 10. & $\begin{array}{l}\text { Instructional objectives } \\
\text { appropriate for technology- } \\
\text { supported instruction. }\end{array}$ & 17. & $\begin{array}{l}\text { Opinions about applying } \\
\text { technology to instruction } \\
\text { management. }\end{array}$ & 4. & $\begin{array}{l}\text { Teacher understanding } \\
\text { of technology-supported } \\
\text { assessments. }\end{array}$ \\
\hline 11. & $\begin{array}{l}\text { Selecting appropriate technology } \\
\text { tools for content presentation. }\end{array}$ & & & 5. & $\begin{array}{c}\text { Distinctive features of } \\
\text { technology-supported } \\
\text { assessments }\end{array}$ \\
\hline 12. & $\begin{array}{l}\text { Selection and use of teaching } \\
\text { strategies to assist technology- } \\
\text { supported instruction. }\end{array}$ & & & 6 & $\begin{array}{l}\text { Teacher's use of technology- } \\
\text { supported assessments to } \\
\text { evaluate preservice science } \\
\text { teachers in science instruction. }\end{array}$ \\
\hline 13 & $\begin{array}{l}\text { The effects of group collaborations } \\
\text { coupled with technology- } \\
\text { supported instruction. }\end{array}$ & & & & \\
\hline
\end{tabular}

We then used the WLEs and item thresholds to produce a WrightMap. A WrightMap was previously known as the person-item map and is used to display "very complex rating scale data and test data" (Boone, 2014, p. 112). WrightMap allows the Rasch results of the study to be shared with researchers and for those who are unfamiliar with the concept of Rasch modelling, to be able to "digest the results and make sound decisions about complex data" (Boone, 2014, p. 8). The WrightMap also allows the researcher to evaluate how the items of the questionnaire completed by the participants of the study, define traits sufficiently as well as swiftly (Boone, 2014). A WrightMap has two sides. The left side shows the distribution of the respondents weighted likelihood ability estimates from the most able at the top to the least able at the bottom. The options of the items on the right side are distributed from the most difficult (highest threshold) at the top to the least difficult at the bottom. This explains that for each proficiency level 0-4 of the preservice science teachers TPACK-P, there will be an estimated mean.

\section{RESULTS OF RASCH ANALYSIS}

Using Rasch modelling, the thresholds of the 17 questions were established using the WrightMap software. Figure 2 demonstrates the proficiency levels for all 17 questions. For most of the 17 questions, items corresponding to level 3 was selected by the preservice science teachers as the best option to use in the instructional scenarios that were provided to them, while items corresponding to level 1 was chosen as the most unsuitable option to use within these instructional scenarios. Table 2 reveals the thresholds of the proficiency levels of each of the questions. Based on the 103 preservice 
science teachers' responses, the thresholds of the 4 proficiency levels for the 17 questions on the TPACK-P questionnaire were identified. By averaging the thresholds across the items, the thresholds of proficiency levels were located for the dimension of knowledge about TPACK-P as -3.00, -1.47, -0.42 , and 0.50 (logit). Logit is a metric system used within the application of the IRT. Ludlow and Haley (1995) defined logits as the "interval level units of measurement corresponding to the total scores that have undergone an exponential transformation" (p. 969). They are defined as the "natural $\log$ of odds-ratio" (Ludlow, Hayley and Gans, 1992, p. 68).

\section{Validity and Reliability of Assessment from Item Infit and Outfit Statistics}

The mean-square statistics were used to evaluate the validity of our assessment. Two fit-indices were reviewed: information-weighted mean-square (infit MNSQ) and unweighted mean-square (outfit MNSQ). The two fit-indices have different foci: while outfit is more sensitive to unexpected observations by persons on items that are relatively very easy or very hard for the subjects, infit is more sensitive to unexpected patterns of observations by items roughly targeted to them (Smith, Schumacker, \& Busch, 1995). According to David et al. "Whereas the infit statistics deals with overall performance of an item, the outfit statistics are used to analyse if the responses are irregular and sensitive to outliers" (p.81).

These indices "represent the differences between the Rasch model's theoretical expectation of the item performance and the performance actually encountered for that item in the data matrix" (Bond \& Fox, 2015, p. 57). The MNSQ-values of the items should be close to 1. Linacre (2002) explained that thresholds used for these statistics are 0.5 to 1.5 , with 1 being the ideal value. For all 17 questions, the infit and outfit MNSQ were equal to 1.00, and the $t$-values were located in between -1.96 and 1.96. The results suggested that the equal discrimination assumption was sustained (Bond \& Fox, 2015; Jen, Yeh, Hsu, Wu, \& Chen, 2016). Therefore, the proposed PCM was used to interpret the participants' responses on this TPACK instrument.

\section{Distribution of Preservice Science Teachers According to Proficiency Levels}

The preservice science teachers' TPACK-P was estimated by weighted likelihood estimates (WLEs). According to the means of thresholds for the proficiency levels in Table 2, WLE between -3.00 and -1.47 , places them on level 1 , between -1.47 and -0.42 places them on level 2 , between -0.42 and 0.50 places preservice science teachers on level 3 and from 0.50 and higher places preservice science teachers on the highest proficiency level of 4.

Table 3 shows the distribution of preservice science teachers on the different proficiency levels of TPACK-P. As demonstrated by Table 3, 82.52\% of preservice science teachers have a proficiency level 3 for their knowledge on TPACK-P. A proficiency level of 3 demonstrates the infusive application, where the teacher makes use of ICTs to guide learners to self-explore and independently construct their science knowledge. Only $9.70 \%$ of the preservice science teachers were located at level 4 where they are adept at using their experience-based TPACK to employ ICTs in assisting their learners in learning science. Considering the great number of preservice science teachers found on level 3 proficiency of TPACK-P, the knowledge of TPACK-P by these preservice science teachers is quite high.

\section{DISCUSSION AND CONCLUSION}

TPACK-P is a knowledge developed by teachers over a period of time using their experiences in longterm planning and instruction using ICT to support their different teaching needs. With the roll-out of currently taking place in South Africa school classrooms, the need for teachers to effectively implement technology becomes a key imperative, and this underline the importance for in-service teachers to have high proficiency in TPACK-P. To ensure teachers are well-developed in the implementation of technology in the classroom, tertiary institutions need to ensure that their teacher education programs have a strong curriculum focus on ICT integration. As we have seen in this research study, $82.52 \%$ of 
Figure 2. Item thresholds in Wright Map

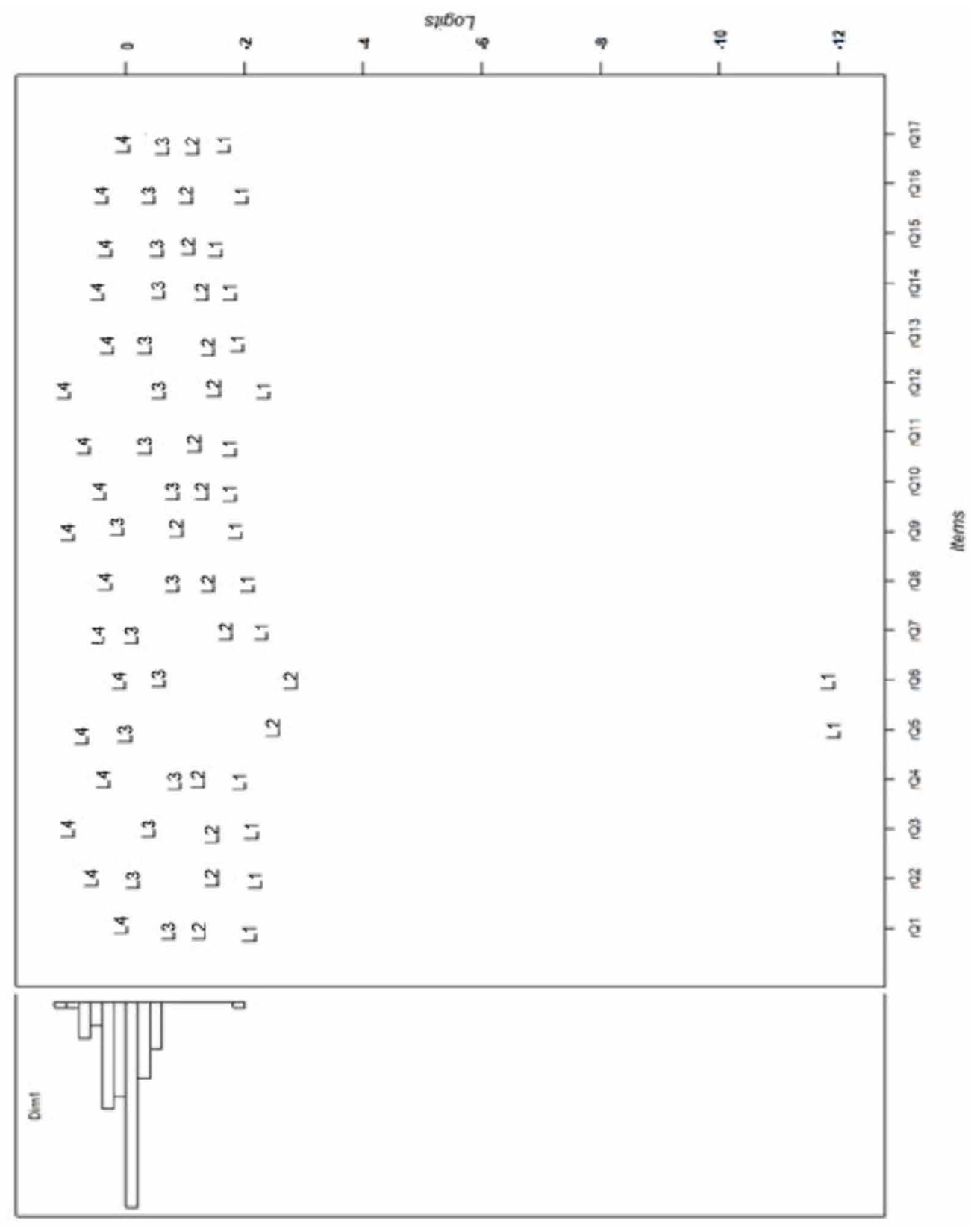

uoenqusip uosiod out

preservice science teachers at a South African university demonstrated a proficiency level 3 for their knowledge on TPACK-P. While this is an encouraging result, it is a concern that $7.78 \%$ of student teachers operate at demonstrate proficiency at levels 1 and 2 . These two levels either demonstrate the preservice science teachers on a simple adoption level where teachers use ICTs to help the learners learn about science via more teacher-centred strategies or with less well-founded rationales, 
Table 2. Thresholds of the proficiency levels for the questions in TPACK-P

\begin{tabular}{|c|c|c|c|c|}
\hline Item no. & Level 1 & Level 2 & Level 3 & Level 4 \\
\hline Q1 & $-2,0094$ & $-1,1990$ & $-0,7310$ & 0,0129 \\
\hline Q2 & $-2,1296$ & $-1,7165$ & $-0,1302$ & 0,5212 \\
\hline Q3 & $-2,0159$ & $-1,7359$ & $-0,3811$ & 1,0555 \\
\hline Q4 & $-1,7901$ & $-1,3136$ & $-1,0207$ & 0,4497 \\
\hline Q5 & $-11,9999$ & $-2,6163$ & 0,1335 & 0,7127 \\
\hline Q6 & $-11,9999$ & $-2,7159$ & $-0,5582$ & 0,2511 \\
\hline Q7 & $-2,1567$ & $-1,7511$ & $-0,0337$ & 0,4388 \\
\hline Q8 & $-1,8809$ & $-1,4039$ & $-0,7907$ & 0,3078 \\
\hline Q9 & $-1,9615$ & $-0,8943$ & 0,1667 & 0,9161 \\
\hline Q10 & $-1,3642$ & $-1,2646$ & $-0,9282$ & 0,4781 \\
\hline Q11 & $-1,7079$ & $-1,3217$ & $-0,3496$ & 0,6763 \\
\hline Q12 & $-2,2436$ & $-1,3907$ & $-0,4543$ & 1,0247 \\
\hline Q13 & $-1,7472$ & $-1,3569$ & $-0,1319$ & 0,1806 \\
\hline Q14 & $-1,4858$ & $-1,2854$ & $-0,7222$ & 0,5054 \\
\hline Q15 & $-1,2926$ & $-0,9066$ & $-0,4743$ & 0,3838 \\
\hline Q16 & $-1,9454$ & $-0,9742$ & $-0,3719$ & 0,5228 \\
\hline Q17 & $-1,3320$ & $-1,1732$ & $-0,4236$ & 0,0570 \\
\hline Mean & $-3,0037$ & $-1,4718$ & $-0,4236$ & 0,4997 \\
\hline SD & 3,3985 & 0,5171 & 0,34850 & 0,3050 \\
\hline SE & 0,1999 & 0,03042 & 0,0205 & 0,0179 \\
\hline
\end{tabular}

Table 3. Distribution of preservice science teachers on different proficiency levels of TPACK-P

\begin{tabular}{|l|l|}
\hline \multicolumn{1}{|c|}{ Proficiency level } & \multicolumn{1}{|c|}{$\%$ Pre-service science teachers } \\
\hline Level 1 & $0.99 \%$ \\
\hline Level 2 & $6.79 \%$ \\
\hline Level 3 & $82.52 \%$ \\
\hline Level 4 & $9.70 \%$ \\
\hline
\end{tabular}

or teachers with a basic understanding of technology resulting from their limited experience in the implementation of ICTs in the classroom. We maintain that making the transition toward higher levels of TPACK-P should be a target for future teacher education. It is also a recommendation that due to the pre-service teachers at the South African university that formed the focus of this study having very adequate proficiency in TPACK-P that some of the curriculum support materials that have been developed be made available to the provincial and national departments of education for possible use in their in-service teacher upliftment programmes that address ICT integration.

A limitation of this study is a lack of triangulation in data collection with the TPACK-P questionnaire being the sole source of data. Chen and Jang (2019) reveal a similar limitation in their research on Taiwanese secondary in-service teachers' TPACK in remarking that the use of self-report 
measures are often susceptible to social desirability bias (Fisher, 1993). It is therefore suggests that future investigations should also include lesson observations to establish how student teachers in their practice enact the indicators of TPACK-P identified in the framework. The current study was also confined to one university, and so it is recommended that a larger-scale study be planned involving other South Africa university. In this way the status on the TPACK-P proficiency of South African preservice science teachers may be more broadly established. Further to this, research could be planned to compare the TPACK-P proficiency of pre-service and in-service teachers. A study conducted in Taiwan using the same 17-item questionnaire found that that there were no significant differences between in-service and pre-service teachers' TPACK-P (Jen, Yeh, Hsu, Wu \& Chen, 2016). It would be of interest to established whether a similar results would be found for South Africa. 


\section{REFERENCES}

Adams, K. A., \& Lawrence, E. K. (2015). Research methods, statistics, and applications. Sage.

Afshari, M., Bakar, K. A., Luan, W. S., Samah, B. A., \& Fooi, F. S. (2009). Factors affecting teachers' use of information and communication technology. Online Submission, 2(1), 77-104.

Angeli, C., \& Valanides, N. (2009). Epistemological and methodological issues for the conceptualization, development, and assessment of ICT-TPCK: Advances in technological pedagogical content knowledge (TPCK). Computers \& Education, 52(1), 154-168. doi:10.1016/j.compedu.2008.07.006

Ay, Y., Karadag, E., \& Bahaddin Acat, M. (2015). The technological pedagogical content knowledge-practical (TPACK-Practical) model: Examination of its validity in the Turkish culture via structural equation modelling. Computers \& Education, 88, 97-108. doi:10.1016/j.compedu.2015.04.017

Babbie, E., \& Mouton, J. (2009). The practice of social research. Oxford University Press.

Bingimlas, K. A. (2009). Barriers to the successful integration of ICT in teaching and learning environments: A review of the literature. Eurasia Journal of Mathematics, Science and Technology Education, 5(3), 235-245. doi:10.12973/ejmste/75275

Bond, T., \& Fox, C. M. (2015). Applying the Rasch model: Fundamental measurement in the human sciences (2nd ed.). Mahwah, NJ: Lawrence.

Boone, W. J. (2014). Rasch analysis in the human sciences. Springer. doi:10.1007/978-94-007-6857-4

Carlson, K. A., \& Winquist, J. R. (2018). An introduction to Statistics An active learning approach (2nd ed.). Sage.

Chen, Y.-H., \& Jang, S.-J. (2019). Exploring the relationship between self-regulation and TPACK of Taiwanese secondary in-service teachers. Journal of Educational Computing Research, 57(4), 978-1002. doi: $10.1177 / 0735633118769442$

Cochran, K. F., DeRuiter, J. A., \& King, R. A. (1993). Pedagogical content knowing: An interactive model for teacher preparation. Journal of Teacher Education, 44(4), 23-272. doi:10.1177/0022487193044004004

Creswell, J. W. (2014). Research design: Qualitative, quantitative, and mixed methods approaches (4th ed.). Sage.

Creswell, J. W., \& Plano Clark, V. L. (2010). Designing and conducting mixed methods research (2nd ed.). Sage.

David, S. L., Hitchcock, J. H., Ragan, B., Brooks, G., \& Starkey, C. (2018). Mixing interviews and Rasch modelling: Demonstrating a procedure used to develop an instrument that measures trust. Journal of Mixed Methods Research, 12(1), 75-94. doi:10.1177/1558689815624586

Department of Basic Education (DBE). (2011). Curriculum Assessment and policy Statement (CAPS) Life Sciences. Government Printers.

Dupagne, M., \& Krendl, K. A. (1992). Teachers' attitude toward computers: A review of literature. Journal of Research on Computing in Education, 24, 420-429.

Falk, A. (2012). Teachers learning from professional development in elementary science: Reciprocal relations between formative assessment and pedagogical content knowledge. Science Education, 96(2), 265-290. doi: $10.1002 /$ sce. 20473

Fan, Y. C., Wang, T. H., \& Wang, K. H. (2012). A web-based model for developing assessment literacy of secondary in-service teachers. Computers \& Education, 57(2), 1727-1740. doi:10.1016/j.compedu.2011.03.006

Ferreira, G. (2010). The tools of the trade: A brief look at instructional media. In H. Van Rooyen \& J. De Beer (Eds.), Teaching Science. Gauteng: Macmillan South Africa Publishers (Pty) Ltd.

Ford, M., \& Botha, A. (2010). A pragmatic framework for integrating ICT into education in South Africa. 2010 IST-Africa, 1-10.

Foster, L., Diamond, I., \& Jefferies, J. (2012). Beginning statistics: An introduction for social scientists. Sage.

Hadley, M., \& Sheingold, K. (1993). Commonalities and distinctive patterns in teachers' integration of computers. American Journal of Education, 101(3), 261-315. doi:10.1086/444044 
Harris, J. B., \& Hofer, M. J. (2011). Technological Pedagogical Content Knowledge (TPACK) in action: A descriptive study of secondary teachers' curriculum-based, technology related instructional planning. Journal of Research on Technology in Education, 43(3), 211-229. doi:10.1080/15391523.2011.10782570

Hennessy, S., Haßler, B., \& Hofmann, R. (2015). Challenges and opportunities for teacher professional development in interactive use of technology in African schools. Technology, Pedagogy and Education, 24(5), 1-28. doi:10.1080/1475939X.2015.1092466

Hsu, Y.-S., Yeh, Y.-F., \& Wu, H.-K. (2015). The TPACK-P framework for science teachers in a practical teaching context. In Y.-S. Hsu (Ed.), Development of science teachers' TPACK: East Asian practices (pp. 17-32). Springer. doi:10.1007/978-981-287-441-2_2

Jang, S.-J., \& Chen, K.-C. (2010). From PCK to TPACK: Developing a transformative model for preservice science teachers. Journal of Science Education and Technology, 19(6), 553-564. doi:10.1007/s10956-010-9222-y

Jang, S. J., \& Tsai, M. F. (2012). Exploring the TPACK of Taiwanese elementary mathematics and science teachers with respect to use of interactive whiteboards. Computers \& Education, 59(2), 327-338. doi:10.1016/j. compedu.2012.02.003

Jen, T.-H., Yeh, Y.-F., Hsu, Y.-S., Wu, H.-K., \& Chen, K.-M. (2016). Science teachers' TPACK-Practical: Standard-setting using an evidence-based approach. Computers \& Education, 95, 45-62. doi:10.1016/j. compedu.2015.12.009

Jimoyiamis, A. (2010). Designing and implementing an integrated technological pedagogical science knowledge framework for science teachers' professional development. Computers \& Education, 55(3), 1259-1269. doi:10.1016/j.compedu.2010.05.022

Johnson, R. B., Onwuegbuzie, A. J., \& Turner, L. A. (2007). Toward a definition of mixed methods research. Journal of Mixed Methods Research, 1(2), 112-133. doi:10.1177/1558689806298224

Jorde, D. (2007). Promoting science inquiry- new possibilities using ICT. Paper presented at the Linnaeus tercentenary symposium, Uppsala University, Uppsala, Sweden.

Koehler, M. J., Mishra, P., \& Cain, W. (2013). What is technological pedagogical content knowledge (TPACK)? Journal of Education, 193(3), 13-19. doi:10.1177/002205741319300303

Kuhn, T. S. (1970). The structure of scientific revolutions. University of Chicago Press.

Lee, E., Brown, M. N., Luft, J. A., \& Roehrig, G. H. (2007). Assessing beginning secondary science teachers' PCK: Pilot year results. School Science and Mathematics, 107(2), 52-60. doi:10.1111/j.1949-8594.2007.tb17768.x

Lee, E., \& Luft, J. A. (2008). Experienced secondary science teachers' representation of pedagogical content knowledge. International Journal of Science Education, 30(10), 1343-1363. doi:10.1080/09500690802187058

Linacre, J. M. (2009). The efficiency of Warm's weighted mean likelihood estimate (WLE) correction to maximum likelihood estimate (MLE) bias. Rasch Measurement Transactions, 23(1), 1188-1189.

Ludlow, L. H., \& Haley, S. M. (1995). Rasch model logits: Interpretation, use, and transformation. Educational and Psychological Measurement, 55(6), 967-975. doi:10.1177/0013164495055006005

Ludlow, L. H., Hayley, S. M., \& Gans, B. M. (1992). A hierarchical model of functional performance in rehabilitation medicine: The Tufts assessment of motor performance. Evaluation \& the Health Profession, 15, 59-74.

Lux, N., Bangert, A., \& Whittier, D. (2011). The development of an instrument to assess preservice teacher's technological pedagogical content knowledge. Journal of Educational Computing Research, 45(4), 415-431. doi:10.2190/EC.45.4.c

Maeng, J. L., Mulvey, B. K., Smetana, L. K., \& Bell, R. L. (2013). Preservice teachers' TPACK: Using technology to support Inquiry instruction. Journal of Science Education and Technology, 22(6), 838-857. doi:10.1007/ s10956-013-9434-z

Magnusson, S., Krajcik, J., \& Borko, H. (1999). Nature, sources, and development of pedagogical content knowledge for science teaching. In J. Gess-Newsome \& N. G. Lederman (Eds.), Examining pedagogical content knowledge: The construct and its implications for science education (pp. 95-132). Kluwer. 
Marlow, C. (2001). Research methods for generalist social work. Brooks/Cole.

Masters, G. N. (1988). The analysis of partial credit scoring. Applied Measurement in Education, 1(4), 279-297. doi:10.1207/s15324818ame0104_2

Matthews, B., \& Ross, L. (2010). Research Methods: A practical guide for social sciences. Pearson Education.

McAuley, C. (2003). Ethics. In R.L Miller \& D. Brener (Eds.), The A-Z of Social research. London: Sage.

McMillan, J. H., \& Schumacher, S. (2010). Research in education: Evidence-based inquiry (6th ed.). Pearson Education.

Merriam, S. B. (1998). Qualitative Research on case study applications in education. Revised and expanded from "Case study Research in Education.". ERIC.

Mishra, P., \& Koehler, M. J. (2006). Technological pedagogical content knowledge: A framework for teacher knowledge. Teachers College Record, 108(6), 1017-1054. doi:10.1111/j.1467-9620.2006.00684.x

Moseley, D., \& Higgins, S. (1999). Ways forward with ICT: Effective pedagogy using information and communications technology for literacy and numeracy in primary schools. Teacher Training Agency.

Mumtaz, S. (2000). Factors affecting teachers' use of information and communications technology: A review of the literature. Journal of Information Technology for Teacher Education, 9(3), 319-342. doi:10.1080/14759390000200096

National Research Council. (2000). Inquiry and the national science education standards: A guide for teaching and learning. National Academic Press.

Pfundt, H., \& Duit, R. (2000). Bibliography: Students' alternative frameworks and science education (5th ed.). University of Kiel.

Pretoria Department of Education. South Africa. (2004). White Paper on e-Education: Transforming Learning and Teaching through ICT. Pretoria: Author.

Ramnarain, U., \& Modiba, M. (2013). Critical friendship, collaboration and trust as a basis for self-initiated professional development: A case of science teaching. International Journal of Science Education, 35(1), 65-85. doi:10.1080/09500693.2012.742593

Ramnarain, U., \& Moosa, S. (2017). The Use of Simulations in Correcting Electricity Misconceptions of Grade 10 South African Physical Sciences Learners. International Journal of Innovation in Science and Mathematics Education, 25(5), 1-20.

Ritchie, J., \& Lewis, J. (Eds.). (2003). Qualitative research practice: a guide for social science preservice science teachers and researchers. Sage.

Rosen, L. D., \& Weil, M. M. (1995). Computer availability, computer experience, and technophobia among public school teachers. Computers in Human Behavior, 11(1), 9-31. doi:10.1016/0747-5632(94)00018-D

Sheffield, R., Dobozy, E., Gibson, D., Mullaney, J., \& Campbell, C. (2015). Teacher education preservice science teachers using TPACK in science: A case study. Educational Media International, 52(3), 227-238. do i:10.1080/09523987.2015.1075104

Shulman, L. S. (1986). Those who understand knowledge growth in teaching. Educational Research, 15(2), 4-14. doi:10.3102/0013189X015002004

Shulman, L. S. (1987). Knowledge and teaching: Foundations of the new reform. Harvard Educational Review, 57(1), 1-22. doi:10.17763/haer.57.1.j463w79r56455411

Smith, R. M., Schumacker, R. E., \& Busch, M. J. (1995, April). Using item mean squares to evaluate fit to the Rasch model. Paper presented at the Annual Meeting of the American Educational Research Association, San Francisco, CA.

Stott, A. (2010). Technology and science. In U. Ramnarain (Ed.), Teaching scientific investigations. Macmillan South Africa. 
Tao, J., Shi, N.-Z., \& Chang, H.-H. (2012). Item-weighted likelihood method for ability estimation in tests composed of both dichotomous and polytomous items. Journal of Educational and Behavioral Statistics, 37(2), 298-315. doi:10.3102/1076998610393969

Taylor, S. J., Bogdan, R., \& DeVault, M. (2015). Introduction to qualitative research methods: A guidebook and resource (4th ed.). John Wiley \& Sons.

Thissen, D., \& Steinberg, L. (2012). Item response theory. In R. E. Millsap \& A Maydeu-Olivares (Eds.), The SAGE handbook of quantitative methods in psychology. London: Sage. doi:10.4135/9780857020994

Tokmak, H. S. (2015). Preservice teachers' perceptions on TPACK development after designing educational games. Asia-Pacific Journal of Teacher Education, 43(5), 392-410. doi:10.1080/1359866X.2014.939611

Turner, D. W. (2010). Qualitative interview design: A practical guide for novice investigators. Qualitative Report, 15(3), 754-760.

Van Driel, J., Beijaard, D., \& Verloop, N. (2001). Professional development and reform in science education: The role of teachers' practical knowledge. Journal of Research in Science Teaching, 38(2), 137-158. doi:10.1002/10982736(200102)38:2<137::AID-TEA1001>3.0.CO;2-U

Van Driel, J. H., Verloop, N., \& de Vos, W. (1998). Developing science teachers' pedagogical content knowledge. Journal of Research in Science Teaching, 35(6), 673-695. doi:10.1002/(SICI)1098-2736(199808)35:6<673::AIDTEA5>3.0.CO;2-J

Warm, T. A. (1989). Weighted likelihood estimation of ability in item response theory. Psychometrika, 54(3), 427-450. doi:10.1007/BF02294627

Winnans, C., \& Brown, D. S. (1992). Some factors affecting elementary teachers' use of the computer. Computers \& Education, 18(4), 301-309. doi:10.1016/0360-1315(92)90102-B

Wu, M., Tam, H. P., \& Jen, T.-H. (2016). Educational measurement for applied researchers: Theory into practice. Springer. doi:10.1007/978-981-10-3302-5

Yeh, Y.-F., Hsu, Y. S., Wu, H.-K., Hwang, F.-K., \& Lin, T. C. (2014). Developing and validating technological pedagogical content knowledge-practical (TPACK-Practical) through the Delphi survey technique. British Journal of Educational Technology, 45(4), 707-722. doi:10.1111/bjet.12078

Yeh, Y.-F., Hwang, F.-K., \& Hsu, Y.-S. (2015). Applying TPACK-P to a Teacher Education Program. In Development of Science Teachers' TPACK. Singapore: Springer Science + Business Media. doi:10.1007/978981-287-441-2_5

Yeh, Y.-F., Lin, T.-C., Hsu, Y. S., Wu, H.-K., \& Hwang, F.-K. (2015). Science teachers' proficiency levels and patterns of TPACK in a practical context. Journal of Science Education and Technology, 24(1), 78-90. doi:10.1007/s10956-014-9523-7

Umesh Ramnarain is a professor in science education.

Annesca Pieters is a high school science teacher.

Hsin-Kai Wu is a professor of Graduate Institute of Science Education at the National Taiwan Normal University and a Distinguished Visiting Professor in the Faculty of Education at University of Johannesburg, South Africa. 